IZA DP No. 533

\title{
Assessing Welfare Accounts
}

\author{
Stefan Fölster \\ Robert Gidehag \\ Mike Orszag \\ Dennis Snower \\ J uly 2002
}




\title{
Assessing Welfare Accounts
}

\author{
Stefan Fölster \\ Confederation of Swedish Enterprise \\ Robert Gidehag \\ The Swedish Research Institute of Trade \\ Mike Orszag \\ Watson Wyatt and IZA Bonn \\ Dennis Snower \\ Birkbeck College, University of London, CEPR and IZA Bonn
}

\author{
Discussion Paper No. 533 \\ July 2002
}

\author{
IZA \\ P.O. Box 7240 \\ D-53072 Bonn \\ Germany \\ Tel.: +49-228-3894-0 \\ Fax: +49-228-3894-210 \\ Email: iza@iza.org
}

This Discussion Paper is issued within the framework of IZA's research area Welfare State and Labor Market. Any opinions expressed here are those of the author(s) and not those of the institute. Research disseminated by IZA may include views on policy, but the institute itself takes no institutional policy positions.

The Institute for the Study of Labor (IZA) in Bonn is a local and virtual international research center and a place of communication between science, politics and business. IZA is an independent, nonprofit limited liability company (Gesellschaft mit beschränkter Haftung) supported by the Deutsche Post AG. The center is associated with the University of Bonn and offers a stimulating research environment through its research networks, research support, and visitors and doctoral programs. IZA engages in (i) original and internationally competitive research in all fields of labor economics, (ii) development of policy concepts, and (iii) dissemination of research results and concepts to the interested public. The current research program deals with (1) mobility and flexibility of labor, (2) internationalization of labor markets, (3) welfare state and labor market, (4) labor markets in transition countries, (5) the future of labor, (6) evaluation of labor market policies and projects and (7) general labor economics.

IZA Discussion Papers often represent preliminary work and are circulated to encourage discussion. Citation of such a paper should account for its provisional character. A revised version may be available on the IZA website (www.iza.org) or directly from the author. 
IZA Discussion Paper No. 533

July 2002

\section{ABSTRACT}

\section{Assessing Welfare Accounts}

The paper examines the possible effects of introducing a large-scale welfare reform in Sweden, namely, the introduction of comprehensive welfare accounts. Under this policy, individuals make mandatory contributions to accounts, which they can top up with voluntary contributions. In return, individuals' welfare benefits are paid from their accounts. The paper uses a large panel of individual income data to examine how the adoption of universal welfare accounts may affect economic activity. We find that this policy could be designed so as to reduce social insurance expenditure considerably, improve the incentives to work and save, all with relatively small redistributive impact.

JEL Classification: H11, H21, H23, H51, H52, H53, H55

Keywords: welfare reform, welfare accounts, social insurance, taxes, welfare state benefits

Dennis Snower

Department of Economics

Birkbeck College

University of London

7 Gresse Street

London W1P 1LL

UK

Tel.: +44 (207) 6316408

Fax: +44 (207) 6316416

Email: dsnower@economics.bbk.ac.uk 


\section{$1 \quad$ Introduction}

Sweden recently implemented a pension reform which includes a system of individual accounts giving individuals substantial flexibility in their choice of investments. At the same time, other Swedish social insurance systems such as unemployment insurance, sickness benefits and parental leave have remained unchanged. Like numerous other OECD countries, Sweden faces a serious challenge in welfare policy making. Existing welfare benefits are associated with substantial market distortions and create disincentives to work.

This paper examines the possible effects of introducing a large-scale welfare reform in Sweden, namely, the introduction of comprehensive welfare accounts. Under this policy, individuals make mandatory contributions to accounts, which they can top up with voluntary contributions. In return, individuals' welfare benefits are paid from their accounts. Moving from the traditional tax-financed welfare systems to a welfare accountbased system involves replacing general taxes by mandatory saving to finance the requisite welfare benefits. The welfare accounts are hence like ordinary savings accounts with two key exceptions. First, to avoid problems of moral hazard, there are restrictions on withdrawals from the welfare accounts. And second, the welfare accounts also serve a redistributive function, so that individuals receive specific minimum welfare benefits regardless of how low their account balances may be. ${ }^{1}$ Such accounts are in place on a comprehensive basis in Singapore, and for specific benefits such as unemployment, health and education in the US, Chile and Brazil.

In order to motivate the introduction of welfare accounts, ${ }^{2}$ we note that social insurance programmes involve a combination of savings, insurance and redistribution. In traditional social insurance programmes, this combination is often far from transparent to the average consumer (or anyone else, for that matter!). The Swedish welfare system is a case in point. Individuals receive a panoply of benefits but neither the cost of each nor the

\footnotetext{
${ }^{1}$ The welfare accounts would hence operate somewhat like the new Swedish premium pension accounts but would apply to benefits more generally.

2 Theoretical analyses of welfare accounts are presented in Fölster \& Trofimov (1999); Orszag \& Snower (1997), and Orszag, Orszag, Snower and Stiglitz (1999).
} 
degree of cross-subsidy is transparent. Even the new Premium Pension system is not entirely transparent on how movements in mortality are smoothed into changes in retirement benefits.

In addition to lack of transparency, another problem with traditional welfare systems is lack of flexibility. Whereas private compensation and benefit arrangements have moved increasingly towards benefits that are responsive to individuals' personal circumstances, public welfare benefits remain relatively rigid in this regard.

The lack of transparency and flexibility in the traditional welfare systems have adverse incentive effects, since individuals do not have to bear the consequences of their own actions. If an individual claims insurance, it does not effect his or her subsequent contribution rates. The costs of claiming social insurance are thus not internalised and as a result have excessive incentives to claim social benefits.

Yet another major problem is that the benefits provided by traditional welfare systems are devoted, in large part, to redistributions across individuals' lifecycles, rather than to promoting income equality or providing insurance against adverse economic circumstances in a lifetime perspective. We will argue that lifecycle redistributions enabling income smoothing over an individual's lifetime - can be performed more efficiently through comprehensive welfare accounts than through traditional welfare benefits. A major insight in recent economic research is that life-time income tends to be much more equally distributed than income in any particular year. An OECD study on income mobility, for example, indicates that the majority of individuals in the lowest income quintile in 1986 had moved up five years later (Sawyer, 1997). In fact, one in five had moved up at least two quintiles. A Swedish study (Hussenius \& Selén, 1994) that estimated income distributions over the entire life cycle concluded that the lowest quintile only had 31 percent lower life time income than the highest quintile, while annual incomes were four times higher in the highest quintile than in the lowest.

Studies from several welfare states indicate that as little as 20-25 percent of social transfers may actually redistribute between individuals, while the remaining 75-80 percent merely smoothes income over the individual's life cycle (Hussénius and Sélen, 1994; Fölster, 1998). The taxes that need to be levied to finance these transfers inevitably distort economic incentives, reducing the incentive to work, save and invest. In addition, 
the tax-and-transfer systems are run by costly bureaucracies. Thus, there could be substantial efficiency gains from a reform that focuses public welfare provision on the $20-25 \%$ of current expenditure devoted to the achievement of interpersonal redistribution and social insurance against adverse economic circumstances with significant lifetime income implications.

In order to enable individuals to use their welfare accounts to perform lifecycle redistributions, the government must permit them to have negative balances on their welfare accounts during their working lifetimes, thereby enabling them to shift purchasing power through time. In accordance with the government redistributive objectives, people with negative account balances at the end of their working lives are eligible for public support. For those people, the incentives to work and save will inevitably be impaired, but - as we will see below - they may be expected to be small in number in comparison with those who have negative account balances in any particular year. Since lifetime incomes are distributed more equally than annual incomes, as noted, welfare accounts tend to impair incentives of far fewer people than do the traditional taxbased systems.

When the welfare state was first introduced, family structures were more uniform, benefits were more basic and technology was simpler. In such a setting it was both unnecessary to have differentiated benefits and technologically not possible. Flexible benefits and transparency requires good and transparent information technology. While it would have been inconceivable to implement a transparent, flexible benefits policy in the interwar period or even in the 1950s and 1960s, it is technologically possible today.

In short, welfare accounts promise a number of significant advantages over the traditional welfare systems. In particular, by permitting the government to focus on interpersonal redistribution and social insurance against economic circumstances with significant lifetime income implications, the reform may allow substantial reductions in taxes and thereby improve people's incentives to work, save, and invest. Furthermore, by helping people internalize the social cost of their welfare expenditures, welfare accounts discourage people from making excessive welfare claims. In so doing, welfare accounts also improve people's incentive to work. 
This paper uses a large panel of individual income data to examine how the adoption of universal welfare accounts may affect economic activity. We find that this policy could be designed so as to reduce social insurance expenditure considerably, improve the incentives to work and save, all with relatively small redistributive impact. Our simulations indicate that when the redistribution among welfare account balances is sufficient to ensure that people receive at least as much as under the current system, the move to universal welfare accounts is associated with substantial reduction in taxes, rises in after-tax incomes, and improvements in work incentives.

\section{Simple Examples}

It is useful to illustrate the effects of moving from tax-financed welfare benefits to individual welfare accounts with a sequence of simple examples. The data for the first is given in Table 1. In each period of analysis, there are equal numbers of individuals of two types who live for just two periods. Individual type A has income $y$ in the first period and zero income in the second, whereas individual type B has zero income in the first period and income $y$ in the second. Within each period their incomes are therefore characterized by a high degree of inequality. Observe, however, that lifetime income is equally distributed, if we ignore time discounting.

Suppose that the government specifies that when income drops to zero, the person is entitled to a benefit of $\beta y$. We assume, plausibly, that $\beta<1 / 2$ i.e. the replacement ratio is less that half of the income of the richest individual. A conventional tax-financed welfare system requires that the per-period benefit $\beta y$ be financed through taxes on the income earners. Thus the government's budget constraint is $\beta y=t_{T B} y$, where $t_{T B}$ is the tax rate under the "tax based" (TB) welfare system. Thus the tax rate is $t_{T B}=\beta$.

In an account-based social insurance system, individuals use their welfare accounts to shift income between periods. Individual A saves in the first period and withdraws money in the second; whereas individual B borrows in the first period and 
repays in the second. ${ }^{3}$ Since lifetime incomes are equal across the two individuals, the tax rate $t_{A B}$ under the account-based system (where subscript $\mathrm{AB}$ stands for "account-based") is zero. The core reason that accounts could improve economic outcomes is that this lower tax rate provides better incentives for all to work.

Table 11.1: Welfare accounts versus tax-financed benefits in the absence of redistribution (under flat-rate guaranteed minimum income)

\begin{tabular}{lll}
\hline People & 1 & 2 \\
\hline $\mathrm{A}$ & $\mathrm{y}$ & 0 \\
$\mathrm{~B}$ & 0 & $\mathrm{y}$ \\
& & \\
Tax Rates & $\mathrm{t}_{\mathrm{TB}}$ & $\mathrm{t}_{\mathrm{AB}}$ \\
& $\beta$ & 0 \\
& & \\
\hline
\end{tabular}

Next consider a second example, in which the individual's lifetime incomes are not equal. Here the redistributive function of welfare accounts comes into play. In particular, Individual A once again has income $y$ in the first period and zero income in the second, but individual B now has zero income in the first period and income $\theta y$ in the second. Thus, whereas the lifetime income of $\mathrm{A}$ is $y$, that of $\mathrm{B}$ is $\theta y$.

\footnotetext{
${ }^{3}$ In this particular example shifting income over time could of course be achieved in a private capital market. As soon as there is some redistribution, however, there has to be some government involvement in administration of welfare accounts.
} 


\section{Table 11.2: Welfare accounts versus tax-financed benefits with redistribution} (under flat-rate guaranteed minimum income)

\begin{tabular}{lll}
\hline People & 1 & 2 \\
\hline A & $\mathrm{y}$ & 0 \\
$\mathrm{~B}$ & 0 & $\theta \mathrm{y}$ \\
& & \\
Tax Rates & $\mathrm{t}_{\mathrm{TB}}$ & $\mathrm{t}_{\mathrm{AB}}$ \\
& $2 \beta /(1+\theta)$ & $2 \beta-\theta$ \\
& & \\
\hline
\end{tabular}

Under the tax-based welfare system, the tax rate $t_{T B}$ is imposed on the incomes $y$ and $\theta y$ to pay for the welfare benefit $\beta$ per person per period. Thus the government budget constraint is $t_{T B}(y+\theta y)=2 \beta y$. Thus the tax rate is $t_{T B}=2 \beta /(1+\theta)$.

Under the account-based welfare system, by contrast, the redistribution is over lifetime incomes rather than per-period incomes. The lifetime income of individual A is $y$, and that of individual $\mathrm{B}$ is $\theta y$. We have supposed that guaranteed minimum income is $\beta y$; and thus the guaranteed minimum lifetime income is $2 \beta y$. If $2 \beta y<\theta y$ (i.e. the guaranteed minimum lifetime income is less than the lifetime income of the poorer individual), then the tax rate $t_{A B}$ under the account-based system is zero. On the other hand, if $2 \beta y>\theta y$ (i.e. the guaranteed minimum lifetime income is greater than the lifetime income of the poorer individual), then the tax rate on the richer individual must be such as to cover the difference between the guaranteed minimum lifetime income and the actual lifetime income of the poorer individual. Thus, the tax rate $t_{A B}$ fulfills the following government budget constraint: $t_{A B} y=2 \beta y-\theta y$. Thus the account-based tax rate is $t_{A B}=2 \beta-\theta$.

Observe that $t_{A B}<t_{T B}$, since $2 \beta-\theta<2 \beta /(1+\theta)$ is implied by $\beta<(1+\theta) / 2$, which holds since $\beta<1 / 2$

Whereas the two examples above have been deterministic, our last example concerns risky income streams. Suppose that the individuals A and B both face the probability $u$ of being unemployed and receiving zero income - in the absence of 
government intervention - and the probability 1- $u$ of being employed. If employed, individual A receives income $y$ and individual B receives income $\theta y$. Suppose that both individuals live sufficiently long so that their average per-period incomes can be closely approximated by their mean incomes. Then the expected per-period income of individual $\mathrm{A}$ is $(1-u) y$, and that of individual $\mathrm{B}$ is $(1-u) \theta y$.

Table 11.3: Welfare accounts versus tax-financed benefits under stochastic incomes and flat-rate guaranteed minimum income

\begin{tabular}{lll}
\hline People & Expected income & \\
\hline $\mathrm{A}$ & $(1-\mathrm{u}) \mathrm{y}$ & \\
$\mathrm{B}$ & $(1-\mathrm{u}) \theta \mathrm{y}$ & \\
& & $\mathrm{t}_{\mathrm{AB}}$ \\
Tax Rates & $\mathrm{t}_{\mathrm{TB}}$ & $(\beta /(1-\mathrm{u}))-\theta$ \\
& $2(\mathrm{u} /(1-\mathrm{u})(\beta /(1+\theta)$ & \\
\hline
\end{tabular}

Under the traditional tax-based welfare system, the average tax receipts per period are $t_{T B}(y+\theta y)(1-u)$ and the average transfers per period are $\beta y u$ (where $\beta y$ is the minimum guaranteed income per period). Thus the government budget constraint is $t_{T B}(y$ $+\theta y)(1-u)=2 \beta y u$. The associated tax rate is $t_{T B}=2(u /(1-u)(\beta /(1+\theta)$.

Under the account-based system, the tax receipts from the richer individual, $t_{A B}(1-$ u)y are used to finance the difference between the minimum guaranteed income $(\beta y)$ and the expected income of the poorer individual $((1-u) \theta y)$, provided that the former is greater than the latter (i.e. $\beta>((1-u) \theta)$. Moreover, we assume - plausibly - that $\beta<\theta$, i.e. the minimum guaranteed income is less than the income earned by the poorer individual when employed. Thus the associated government budget constraint is $t_{A B}(1-u) y$ $=\beta y-(1-u) \theta y$, and the tax rate therefore is $t_{A B}=(\beta /(1-u))-\theta$.

Once again, the tax rate under the account-based system is less than that under the tax-based system. To see this, note that $t_{A B}<t_{T B}$ implies that $=(\beta /(1-u))-\theta<2(u /(1-u)$ 
$(\beta /(1+\theta)$, which in turn implies that $\Omega=(\beta /(1-u))(1-2 u /(1+\theta))<\theta$. Observe that $d \Omega / d u<0$, so that $\Omega$ attains its maximum when $u=0$. This maximum value of $\Omega$ is $\beta$, which is less than $\theta$.

It is important to note that, although the move from a tax-based to an accountbased welfare system may improve the trade-off between equality and incentives, it certainly does not eliminate it. The more an account-based system attempts to equalize lifetime incomes across individuals, the weaker will be the relation between a person's productivity and income and thus the lower the incentive to be productive. In the previous example, for instance, the tax rates $t_{T B}=2\left(u /(1-u)\left(\beta /(1+\theta)\right.\right.$ and $t_{A B}=(\beta /(1-$ $u$ ) - $\theta$ both rise with $\beta$. Moreover, for plausible unemployment rates (e.g. $u<1$ ), the tax rate under the account-based sys tem rises faster than that under the tax-based system, so that the relative tax advantage of welfare accounts is eroded.

Furthermore, it needs to be emphasized that welfare accounts are not meant to be a substitute for insurance against risks. The point is rather that some risks are more effectively insured in a life-time perspective rather than on a day by day basis. ${ }^{4}$

Yet welfare accounts have a number of important problems. Their increased transparency may lead to calls for less redistribution, thereby harming those less well off. Where individuals have more choice and flexibility, there could be additional selection effects from accounts, raising the cost of provision. Finally, despite advances in modern technology, accounts may be more expensive to administer than traditional social welfare systems. In practice, the size of these costs depends heavily on the detailed provisions determining the way in which the welfare account reform is to be implemented.

\section{Application to Sweden}

Our analysis focuses on a comprehensive reform of the entire Swedish social insurance system. The components of the welfare system we replace with welfare accounts are

\footnotetext{
${ }^{4}$ Also, a welfare account still allows the government to target expenditure on health insurance by regulating which types of expenditure the account can be used for.
} 
listed in Table 11.4 below. In all, the reform we examine involves roughly $21 \%$ of Swedish GDP of which slightly less than half is non pension benefits.

Table 11.4: Benefits and public services encompassed by our analysis ${ }^{1}$

\begin{tabular}{ll}
\hline Benefit & \% of GDP \\
Unemployment benefit & 2 \\
& 3.7 \\
Parental leave & 1.5 \\
Sick Benefit & 1.3 \\
Child Benefit & 1.2 \\
Welfare & 0.93 \\
Housing & 0.62 \\
Pensions & 12.2 \\
\hline
\end{tabular}

1 Not counting public costs of insuring the account.

2 Includes benefits for training during unemployment (AMU).

For our analysis, we used LINDA, a longitudinal Swedish data set containing information on 300000 individuals and members of their households. The sample of individuals is representative for the population during the period 1960 to 1996 . The core of the data are the income registers (Inkomst- och Förmögenhetsstatistiken) available annually from 1968 to 1996, and population census data available every fifth year from 1960 to 1990 . For each year information on all family members of the sampled individuals are added to the data set, but they are included only for as long as they stay in the family.

While LINDA primarily consists of a panel, the sample outflow has been matched by a representative inflow, so that the included individuals are both longitudinally and cross-sectionally representative of the population. Of the 300000 individuals available each year, about 100000 are in the sample over the entire period from 1968 to 1996. 
Since we have such rich historical data on welfare benefits, most of our analysis is retrospective, assuming that welfare reform was actually implemented in 1978 and imputing how accounts would have worked. We also implemented a model which projects costs forward.

We assume that accounts are implemented for individuals up to the age of 45 in 1978. In the initial year individuals start with an account balance that roughly matches what they would have had if the account had been in existence all along. The initial deposit is calculated as a function of the average amount accumulated per person and year multiplied by the number of years that the individual exceeds 18 years of age. The average account accumulationis calculated by simple linear regression. ${ }^{5}$ This procedure resembles the type of transition rules often used when savings based social insurance replaces a conventional system.

There were a number of practical problems in doing the analysis. In particular, the sample cannot be used in the same form over the entire period, as the data become richer over time. From 1968 there is annual information on income, but some components of income, such as social assistance, are shown separately first after 1977. For most of the analysis described below we therefore focus on the period 1978-1996, and on the group of people who were 18-34 years old in 1978. They were 36 to 52 years old in 1996.

The following variables are central to the analysis:

- wage income before taxes (Y),

- taxable government transfers before taxes (B),

- income taxes (T) paid on wage income and on taxable government transfers, and

- non-taxable government transfers, such as social assistance (A).

\footnotetext{
${ }^{5}$ Using a panel with every individual's account balance during each of the 19 years in the panel a simple OLS regression was run:

Balance $=\beta^{*}($ number of years in working life $)+\varepsilon$

In this regression, $\beta$ is 52.000 kronor and significant. This means that the average account balance is accumulated at a rate of 52.000 kronor per year the individual is working. Based on this information we have calculated an imputed value on the account 1978 for each individual in our database.
} 
All economic variables are stated relative to GDP. We further use the long-run equilibrium assumption that the return on accounts is equal to the growth of GDP. The reason for this is that with perfect capital markets, this should be the rate of return both on funded accounts and pay as you go accounts.

Disposable income for individual $\mathrm{i}$ during year $\mathrm{t}$ is

$$
I_{i, t}=Y_{i, t}+B_{i, t}-T_{i, t}+A_{i, t}
$$

The basic system we examine as an alternative to the current tax system requires each individual to save a fraction of his or her wage income in a welfare account. For simplicity, it is assumed that payments into the account replace current social insurance fees (equal to employers' taxes) ${ }^{6}$. These have fluctuated between 27 and 39 percent. We use the actual rate that applies each year, denoted $\sigma_{\mathrm{t}}$. To be precise, the payments into the welfare account $T_{i, t}^{a}=\sigma_{t} Y_{i, t}$, and withdrawals from the account equal $W_{i, t}=B_{i, t}+A_{i, t}$. As noted above the withdrawal $\mathrm{B}_{\mathrm{i}, \mathrm{t}}$ is taxed as in the current system, and these taxes are included in $T_{i, t}$. The balance on the account $\left(b_{i, t}^{a}\right)$ in units of current real per capita GDP then develops as

$b_{i, t}^{a}=b_{i, t-1}^{a}+T_{i, t}^{a}-W_{i, t}$

In this most simple version of the welfare account, the disposable income under the account system equals disposable income under the current inc ome up until retirement. The difference between contributions and withdrawals lies in the accumulation of assets on the account. Since the accumulation on the account provides retirement income it is then necessary to compare the balance on the account with the individuals' implicit wealth provided in the current pension system, $\mathrm{P}_{\mathrm{i}, \mathrm{t}}$. This is calculated as the expected present value of retirement benefits

\footnotetext{
${ }^{6}$ Sweden did not have employees' contributions during the sample period. Otherwise, they would have been included here as well.
} 
If the funds in the account are not sufficient to pay the benefit, the government lends the necessary amount to the individual account. The account system in aggregate is calibrated, however, to ensure that the government's budget is balanced. To calibrate this we have simply calculated the public sector costs, during the entire period we examine (1978-1996), of the welfare systems within the account system. This cost is then compared with the tax cut (whole period) the account reform implies. The money the public sector gains in the years 1978 - 1996 from not handling the welfare systems in the account system very well balance the income loss from the tax cut of social insurance fees the similar period. At retirement age the funds in the account would be converted into an annuity that supplements pension income.

In initial calculations we show how the individual is affected by introducing an account that has no insurance elements at all. This shows how much redistribution the tax-financed system actually has achieved. In later steps a number of insurance elements are introduced. First, the government guarantees a minimum pension to those that retire with insufficient balances. Second, more generous redistribution is considered.

We assume that total payments into the account and withdrawals from the account match, so that no fiscal deficit arises. All current employer and individual social insurance taxes are hence deposited in the individual accounts and the accounts are used to finance all household transfers including pensions. Because the contributions replace taxes, we follow the convention that that there is no tax arising from the contributions. This mirrors the fact in most pension account systems contributions are not taxed, but withdrawals are.

The budget constraint requires that $\Sigma_{i, t} G_{i, t}=\Sigma_{i, t}\left(B_{i, t}+A_{i, t}\right)$ where again $G_{i, t}$ is government expenditure on transfers which is composed of non-taxable transfers A and B are the taxed withdrawals from the account. Over the period 1978 to 1996 transfers to households averaged 14,3\% (net of income taxes, 20,4\% before income taxes) of GDP, while employer tax revenue averaged $14,1 \%$ of GDP.

The feasibility of welfare accounts depends on the extent to which insured events are concentrated in a subgroup of the population. In the extreme, if one group of individuals never earned any wage income and lived entirely off social insurance, while all others never required transfers, then the use of a welfare account would be irrelevant. 
Those who collect benefits would live entirely on the government guarantee. This is a potentially serious problem that could make accounts unworkable. Therefore it is important to assess the extent to which current benefits are paid to people who would end up with a negative account balance. It is important to note in this context that, under the proposed system of universal welfare accounts, people would be allowed to run negative welfare account balances during their working lives. This possibility would not pose a budgetary problem for the government, provided that in aggregate the welfare accounts do not run into deficit on this account.

To examine how many people might end up with negative account balances, we consider the following experiment. We credit accounts with what were previous employer contributions and debit accounts with individual-specific social insurance expenditure. ${ }^{7}$ We show the results in Table 11.5 which shows the average account balance ( $b_{i, t=1996}$ as defined earlier) for all individuals in each decile, where the deciles are based on the account balance at the end of our period divided into deciles.

Table 11.6 shows the same same exercise for guaranteed accounts. The previous experiment has the drawback that it does not include guarantees on account balances so that individuals could conceivably end up with negative account balances and might not hence be able to finance crucial social insurance expenditure. Here, we consider an account system with a guarantee fund financed out of payroll taxes. The tax provides the same guarantee as the current system, that is those people who under the current system are subsidized are guaranteed the same pension that they would have received under the current system. This subsidy is given to about 30 percent of all people.

The tax rate out of compulsory contributions necessary to finance the guarantee in our sample of individuals turns out to be 13.08 percent of payroll. This should be compared to the current rate of 33 percent (of which 27.4 percent should be considered non- actuarial, see section 4).

Tables 11.5 and 11.6 also show the total income accumulated over the 19 years in the account system and in the current system. In the account system the total income is

\footnotetext{
${ }^{7}$ As previously noted, we credit balances in 1978 based on imputed rights. Therefore, this analysis is that of a steady state with fully implemented accounts rather than the effects of accounts starting from scratch.
} 
the sum of individuals' disposible income and the accrued account balance. In the current system the comparable measure is the sum of disposible income and accrued pension rights. ${ }^{8}$

Table 11.5, Account balance in 1996 assuming no insurance provided, average balance per decile, Swedish kronor.

\begin{tabular}{ccccc}
\hline Decile & $\begin{array}{c}\text { Disposable income } \\
\text { during working life }\end{array}$ & $\begin{array}{c}\text { Account balance } \\
1996\end{array}$ & $\begin{array}{c}\text { Sum of disposable } \\
\text { income and account } \\
\text { balance in the } \\
\text { account system }\end{array}$ & $\begin{array}{c}\text { Sum of disposable } \\
\text { income and accrued } \\
\text { pension rights in } \\
\text { the current system }\end{array}$ \\
\hline 1 & 2702452 & -1067704 & 1099964 & 4359943 \\
2 & 2365740 & 225505 & 2704194 & 3974105 \\
3 & 2323020 & 832684 & 3572773 & 4068686 \\
4 & 2440630 & 1228168 & 4283955 & 4389799 \\
5 & 2595759 & 1553069 & 4926719 & 4734779 \\
6 & 2858347 & 1840225 & 5620292 & 5820186 \\
7 & 3132159 & 2130045 & 6329087 & 5850476 \\
8 & 3380445 & 2464883 & 7079922 & 6444781 \\
9 & 3813998 & 2924685 & 8203579 & 7015070 \\
10 & 4939076 & 4069698 & 11047177 & 8206156 \\
\hline
\end{tabular}

Table 11.6, Account balance in 1996 assuming guaranteed accounts, average balance per decile, Swedish kronor. Under guaranteed accounts the same pension as in the current system is guaranteed to the 30 percent of people whose pensions are subsidized in the current system.

\footnotetext{
${ }^{8}$ The accrued pension right is calculated according to the rules in the old pension system (ATP-system) since these are the rules that are relevant for the age group in our sample. In addition drawing rights upon early retirement and sickness benefits have been considered, based on expected values of these benefits for each age and income level.
} 


\begin{tabular}{ccccc}
\hline Decile & $\begin{array}{c}\text { Disposable income } \\
\text { during 1978-96 }\end{array}$ & $\begin{array}{c}\text { Account balance } \\
1996\end{array}$ & $\begin{array}{c}\text { Sum of disposable } \\
\text { income and account } \\
\text { balance in the } \\
\text { account system }\end{array}$ & $\begin{array}{c}\text { Sum of disposable } \\
\text { income and accrued } \\
\text { pension rights in } \\
\text { the current system }\end{array}$ \\
\hline 1 & 2702452 & 1657491 & 4359943 & 4359943 \\
2 & 2365740 & 1657491 & 4023231 & 3974105 \\
3 & 2323020 & 1657491 & 3980511 & 4068686 \\
4 & 2440630 & 1757491 & 4198121 & 4389799 \\
5 & 2595759 & 1979451 & 4575210 & 4734779 \\
6 & 2858347 & 2778565 & 5636912 & 5820186 \\
7 & 3132159 & 2714831 & 5846990 & 5850476 \\
8 & 3380445 & 3141596 & 6522041 & 6444781 \\
9 & 3813998 & 3727632 & 7541630 & 7015070 \\
10 & 4939076 & 4040102 & 8979178 & 8206156 \\
\hline
\end{tabular}

Figure 11.1 shows some summary statistics for the sample. The number of people ending up with negative balances is about 12 percent. This can be contrasted with Feldstein and Altman's (1998) analysis of an unemployment savings account using the Panel Study of Income Dynamics in the U.S. They find that five percent would retire or die with negative balances. One important difference is that in their study all people initially included in the sample work. In our sample in contrast, all people who due to various disabilities never work are included. Another important difference is of course that the account here has a wider scope.

Due to the initial deposit on the account most people that have drawn down their account so much that they have negative balances in any year of the period are people with long-term income losses and tend also to have negative balances at the end of the period. If the initial deposit is excluded, however, a large group of people (34\%) have negative balances at some point over the period, but many $(13,5 \%)$ recover and end up with positive balances. 
Figure 11.1. Share of individuals with negative terminal balances, negative balances ever, and share of individuals that receive compensation in the guaranteed system.

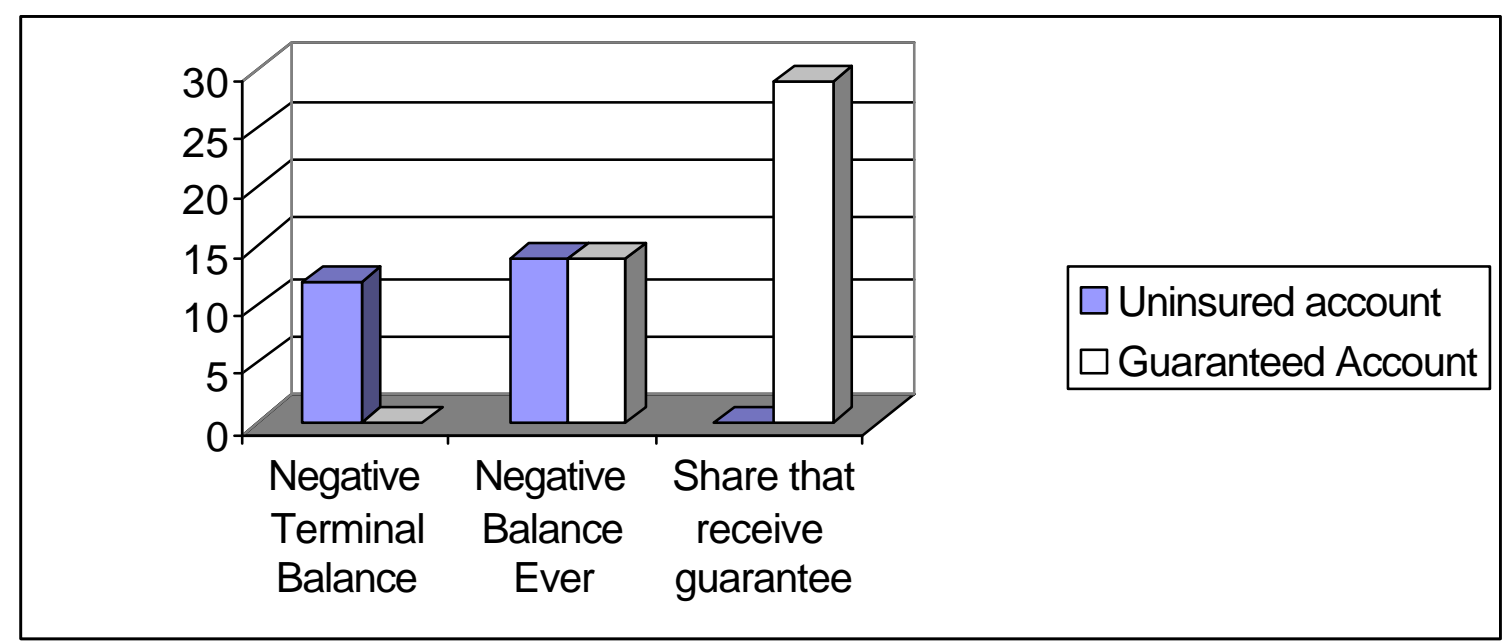

Turning now to the distributional consequences of the account system, table 11.7 shows how total income including accrued pension rights are affected by a switch to the account system. As expected the distributional consequences are considerable as long as no insurance element is added. Interestingly, however, the sum of individual losses is only a small fraction (18\%) of the total employer's tax collected over the period. This supports the argument made above, that only a small share of taxes actually are needed to redistribute between individuals in a life time perspective. The figure indicates the level of balances with guarantees as a function of income deciles. The LINDA dataset as a historical dataset encompasses an ageing population and therefore the positive gains need to be offset by the costs of future liabilities of social expenditure for an ageing population. We did the offset for pensions but not for other social insurance benefits because of the complexity of forecasting age-dependent social insurance benefits into the future. The bottom line is that redistribution based on wealth evels can be much cheaper to finance than the current system of redistribution based on period by period income.

The distributional effects of the uninsured and guaranteed account systems are also illustrated in figure 11.2 below. 
Figure 11.2 The change in life time disposible income when moving to either an uninsured or a guaranted account system, percent change.

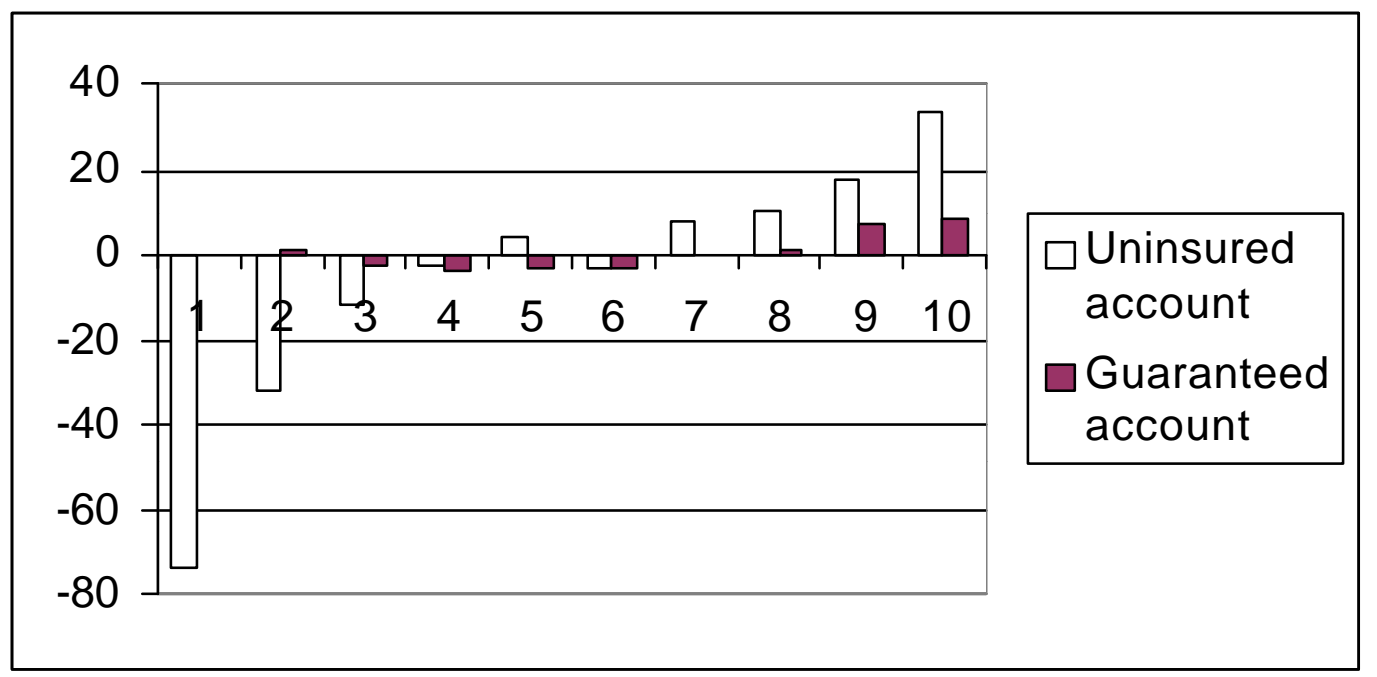

Thus far we have focused on calculations for income deciles. This gives a good picture of how the overall distribution of incomes changes. But even more important is probably how individuals are affected. Does the switch of social insurance system cause great upheaval in the sense that many people move to other income deciles? Do such moves reflect poor insurance or other factors? These questions turn out to be quite difficult conceptually. Table 11.7 shows how individual's life time disposible income is affected by a switch from the current system to an account system. The table shows how many individuals move up or down.

Table 11.7. Share of individuals that move up or down life time disposible income deciles when an account system is introduced, percent.

\begin{tabular}{lcclcccc}
\hline $\begin{array}{l}\text { Income } \\
\text { decile in } \\
\text { current } \\
\text { system }\end{array}$ & $\begin{array}{l}\text { Move } \\
\text { down 3 } \\
\text { deciles }\end{array}$ & $\begin{array}{l}\text { Move } \\
\text { down 2 } \\
\text { deciles }\end{array}$ & $\begin{array}{l}\text { Move } \\
\text { down 1 } \\
\text { decile }\end{array}$ & $\begin{array}{l}\text { Un- } \\
\text { changed }\end{array}$ & $\begin{array}{l}\text { Move up } \\
1 \text { decile }\end{array}$ & $\begin{array}{l}\text { Move up } \\
2 \text { deciles }\end{array}$ & $\begin{array}{l}\text { Move up } \\
3 \text { deciles }\end{array}$ \\
\hline $\begin{array}{l}1-5 \\
\text { decile }\end{array}$ & 0 & 2 & 4 & 81 & 9 & 3 & 1 \\
\hline
\end{tabular}




\begin{tabular}{llllllll}
\hline $\begin{array}{l}6-10 \\
\text { decile }\end{array}$ & 1 & 2 & 7 & 84 & 4 & 2 & 0 \\
All deciles & 1 & 2 & 6 & 82 & 6 & 3 & 0 \\
\hline
\end{tabular}

This table, however, does not settle the issue of whether individual changes are motivated. In the current system insurance has a considerable arbitrary element. A person on parental leave while receiving a high wage will also receive high parental leave compensation. A similar person who has a child while studying receives no compensation - even though this may delay his career and thus cause an income loss as large as the first person's. Similarly, a person who is disabled while working may be fully compensated, while a person who is disabled just a few months before she starts working, receives nothing or only welfare benefits. ${ }^{9}$

In the account system, insurance is less arbitrary. On the other hand, high income earners tend to be less well insured in the sense that a person who has accumulated a large balance on the account and then is disabled or unemployed for long periods, will lose much of the accumulated balance.

As mentioned above, the panel data cannot be used directly to calculate marginal tax effects of introducing welfare accounts. In a companion paper, however, these have been calculated in a simulated panel of individual life cycles. ${ }^{10}$ On average it was shown that marginal effects of taxes and transfers fall from 74 percent to 61 percent. In the next section we turn to some macro-economic effects of introducing welfare accounts.

\section{Simulations of macro-economic effects}

This section adresses two macro-economic effects of introducing welfare accounts. The first concerns the question how sensitive public finances are in the account system to changes in unemployment and retirement age. The second concerns the effect of a reduction in marginal tax effects that an account system may induce. In order to do

\footnotetext{
${ }^{9}$ Many of these problems would arise also with an optimal private insurance.

${ }^{10}$ In that paper (Fölster, 2001) it is also carefully shown that the simulated panel of complete life cycles matches actual panel data well where they can be compared.
} 
this, a simple forecasting model is used to assess likely effects of introducing universal welfare accounts in Sweden.

We consider a population of individuals represented by exogenous characteristics $\theta_{t}$. We represent the level of claims for benefits for an individual by the function:

$$
y_{t}=f\left(y_{t}^{-}, y_{t-k}, \theta_{t}, X_{t}, P_{t}, t ; \beta\right)
$$

which depends on macroeconomic characteristics $X_{t}$, policy characteristics $P_{t}$, as well as other types of benefits $y_{t}^{-}$and lagged benefits. We estimate this relation by panel regression analysis from the LINDA sample.

Our estimates $\hat{y}_{t}$ are then used to construct aggregate benefit expenditure by a weighted sum over the number of individuals with characteristics $\theta_{j}$

$$
\hat{Y}_{t}=\sum_{j=1}^{N} w_{j}\left(\theta_{j}\right) \times f\left(y_{j, t}^{-}, y_{j, t k}, \theta_{j}, X_{t} P_{t}, t ; \hat{\beta}\right)
$$

where $\mathrm{N}$ is the number of individuals in the original sample.

The parameters of (11.3) are estimated in the form of two regressions using the LINDA panel data. The dependent variables are the market income $\left(\mathrm{I}_{\mathrm{i}, \mathrm{t}}\right)$ and the withdrawals $\left(\mathrm{Y}_{\mathrm{i}, \mathrm{t}}\right)$ as a function of the variables described above. Benefits include unemployment benefits, social assistance, sickness benefits, early retirement benefits and others. The following variables are used in the panel: Withdrawals from the individual welfare account $\left(\mathrm{Y}_{\mathrm{t}, \mathrm{i}}\right)$, Labour market income $\left(\mathrm{I}_{\mathrm{t}, \mathrm{i}}\right)$, Age $\left(\mathrm{AGE}_{\mathrm{t}, \mathrm{i}}\right)$, sex $\left(\operatorname{SEX}_{\mathrm{t}, \mathrm{i}} 0=\right.$ man, $1=$ woman), Level of unemployment in percent of the labour force $\left(\mathrm{UNEMP}_{\mathrm{t}}\right)$. All variables are adjusted for inflation and GDP growth. The panel consists of 7120 individuals over 19 years. In detail the regression equations are:

$$
\begin{aligned}
& \mathrm{W}_{\mathrm{it}}=\mathrm{CONSTANT}+\beta \mathrm{W}_{\mathrm{it}-1}+\chi\left(\mathrm{SEX}_{\mathrm{it}}\right)+\alpha\left(\mathrm{AGE}_{\mathrm{it}}\right)+\delta(\mathrm{UNEMP})+\varepsilon .(11.4) \\
& \mathrm{I}_{\mathrm{it}}=\mathrm{CONSTANT}+\beta \mathrm{I}_{\mathrm{it}-1}+\chi\left(\mathrm{SEX}_{\mathrm{it}}\right)+\alpha\left(\mathrm{AGE}_{\mathrm{it}}\right)+\delta(\mathrm{UNEMP})+\varepsilon(11.5)
\end{aligned}
$$

where UNEMP is unemployment measured as total unemployment as percent of the working force in period $\mathrm{t}, \mathrm{W}$ is the withdrawal and $\mathrm{Y}$ is the market income. The results are as in the table 11.8 below. 


\section{Table 11.8. Results of the panel regression}

\section{Dependent variable: Aggregate withdrawals from accounts $Y$.}

$\begin{array}{lcccc} & \text { Unstandardized Coefficients } & \text { Standardized Coefficients } & \text { t } \\ \text { Constant } & \text { B } & \text { Std. Error } & \text { Beta } & -8,47 \\ \text { Y }_{\mathrm{t}-1} & -9621,41 & 1135,90 & & 210,53 \\ \text { SEX } & 0,47 & 0,00 & 0,52 & 14,20 \\ \text { UNEMP } & 6306,60 & 444,18 & 0,03 & 17,73 \\ \text { AGE } & 1175,09 & 66,29 & 0,05 & 14,55\end{array}$

Dependent variable: market income I.

$\begin{array}{lcc} & \text { Unstandardized Coefficients } \\ \text { Constant } & \text { B } & \text { Std. Error } \\ \text { SEX } & 35113,3536 & 1034,120912 \\ \text { UNEMP } & -9981,38 & 425,17 \\ \text { AGE } & -622,27 & 58,53 \\ \text { Ilt-1 } & -70,97 & 24,95 \\ & 0,89 & 0,00\end{array}$

$\begin{array}{cc}\begin{array}{c}\text { Standardized Coefficients } \\ \text { Beta }\end{array} & \mathbf{t} \\ & 33,9547853 \\ -0,03 & -23,48 \\ -0,02 & -10,63 \\ 0,00 & -2,84 \\ 0,88 & 615,92\end{array}$

R 0.89 Adi. R Sa 0.79

In order to calculate projections moving forward, the estimates in Eq. 11.3 and assumed or calculated values of $X_{t}$ and $P_{t}$ and future demographics (which enter into $\left.\theta_{j}\right)$ are substituted into the estimated relationship to calculate the next year's values. Eq. 11.3 is then applied with updated weights to reflect the different distribution of exogenous characteristics in the subsequent year.

We then use these results to simulate. ${ }^{11}$ Note that in the panel we have 7120 individuals in 19 years who are between 18 and 64 years. Therefore this regression should be a good base for a simulation of the withdrawals and payments into the account

\footnotetext{
${ }^{11}$ This exercise does not take account the possibility that the switch to universal accounts may affect macroeconomic variables such as the unemployment rate. Such macroeconomic feedback effects are taken into account at the end of this section.
} 
during an average working life. We simulate a period of 45 years (between 18 and 64 years of age).

We focus on the average person in the economy. If he or she has a surplus on the account, that is enough for a reasonable pension during the years of pension, at the end of the 45 year period - the system on the macro level is in balance. If the balance is not enough, or even negative, pensions will be lower. We also show the costs to the government in terms of percent of GDP if the government wanted to guarantee the same average pension as the current system provides. One should keep in mind, however, that even the current system would probably be cut back or changed if life expectancy increased dramatically, or unemployment remained high over long periods of time.

We consider a policy reform in which the universal welfare account system incorporates redistribution, so that each person's pension level is at least as high as in the current system, in addition to ensuring that the account system is in fiscal balance. Thus the government has to pay money in to the system when the average person's balance is not enough for the pension of the current system. In the empirical model above, we can test whether such government intervention is needed.

Table 11.9, Simulated increase in goverment costs for guarantees in the account system, and development of average pensions, as a function of changes in average unemployment, average age of persons in the working force, and reduced payments into the account.

\begin{tabular}{|c|c|c|}
\hline $\begin{array}{l}\text { Assumptions used in the } \\
\text { simulations }\end{array}$ & $\begin{array}{l}\text { Average annual } \\
\text { pension, } 1000 \text { kronor }\end{array}$ & $\begin{array}{l}\text { Increase in government cost, } \\
\text { percent of GDP }\end{array}$ \\
\hline \multicolumn{3}{|l|}{ Unemployment $4 \%$} \\
\hline Average age & 115 & 0 \\
\hline \multicolumn{3}{|l|}{ Unemployment $6 \%$} \\
\hline Average age & 89 & 1.6 \\
\hline Unemployment $4 \%$ & 99 & 0.96 \\
\hline Average age & & \\
\hline
\end{tabular}


Lower payments into

102

0.89

the account*

Unemployment $4 \%$

Average age $\quad 40$

* Payments into the account are assumed two percentage points of wages lower.

We find that the budgetary viability of the account system is very sensitive to swings in the unemployment rate. Consequently, it appears important that the switch from unemployment benefits to unemployment accounts be included in the adoption of welfare accounts. The reason is that this switch may be expected to improve significantly people's incentives to work. Under an unemployment benefit system, the workers are rewarded for losing their jobs (through the payment of the benefits) and penalized for gaining them (through the payment of income taxes).

Finally, we take macroeconomic behavioural feedbacks into account in several ways. For this purpose, we allow the level of payroll taxes to affect the employment rate.

We divide taxes into two notional categories: (i) the taxes necessary to finance the welfare benefits above and (ii) the remainder, which we may classify as taxes that perform a redistributive function, in a broad sense of the term. We call these the "benefit-financing taxes" and the "redistributive taxes," respectively. In the guaranteed account system, the redistributive tax is reduced to 13.08 percentage points of payroll. In the current system, for example, the payroll tax is 33 percent on top of income, but some $0-10$ percentage points give rise to actuarially fair increases in expected benefits. The remainding 23-33 percentage points may be considered redistributive taxes. The exact figures vary with income levels. For example, people earning more than the maximum income compensated by social insurance face have no actuarial increase in benefits at the margin when they experience an income increase and pay higher payroll taxes. Currently about a third of all income earners earn more than the maximum compensated income in sickness benefits. 
In our Linda sample the average redistributive part of the payroll tax in 1996 was 27,4 percent of payroll. A key question is then how this tax affects labour supply and demand. Since various studies come to somewhat different conclusions, we show the results for various values of the employment elasticity. In the following we define this elasticity as the percent change in the rate of employment that result from a percent change in total taxes on labour. The total tax on labour income is the sum of income taxes and the redistributive share of payroll taxes. Currently these average 52.1 percent of gross labour income (before payroll taxes).

Finally, a key question is how a change in employment affects tax revenue and public expenditure. This is calculated using the same technique as described above to sensitivity of social insurance financing to unemployment. The results imply that in the current system an increase in employment by 1 percent allows a reduction in the redistributive part of the payroll tax by 1.5 percentage points. Then the table below describes how the move to an account system would affect employment and payroll taxes for different assumptions about the elasticity of employment with respect to taxes.

Table 11.10. What could an account system imply for employment and payroll taxes.

\begin{tabular}{llcl}
\hline $\begin{array}{l}\text { Elasticity of } \\
\text { employment with } \\
\text { respect to taxes }\end{array}$ & $\begin{array}{l}\text { Increase in } \\
\text { employment relative } \\
\text { to current system }\end{array}$ & $\begin{array}{l}\text { Payroll tax that } \\
\text { balances public } \\
\text { finances in the } \\
\text { account system }\end{array}$ & $\begin{array}{l}\text { Average } \\
\text { redistributive share } \\
\text { in current payroll tax }\end{array}$ \\
\hline 0 & 0 & 13.08 & 27.4 \\
0.1 & 1.01 & 11.44 & 27.4 \\
0.2 & 2.02 & 9.82 & 27.4 \\
\hline
\end{tabular}

As the table indicates, even modest assumptions about the elasticity of employment with respect to the tax rate imply significant gains of moving to an account based system in terms of increased employment and reduced taxation. These results are illustrated in the figure 11.3. 
Figure 11.3. The consequences of introducing an account for the tax rate and employment with different elasticities of employment with respect to the total tax.

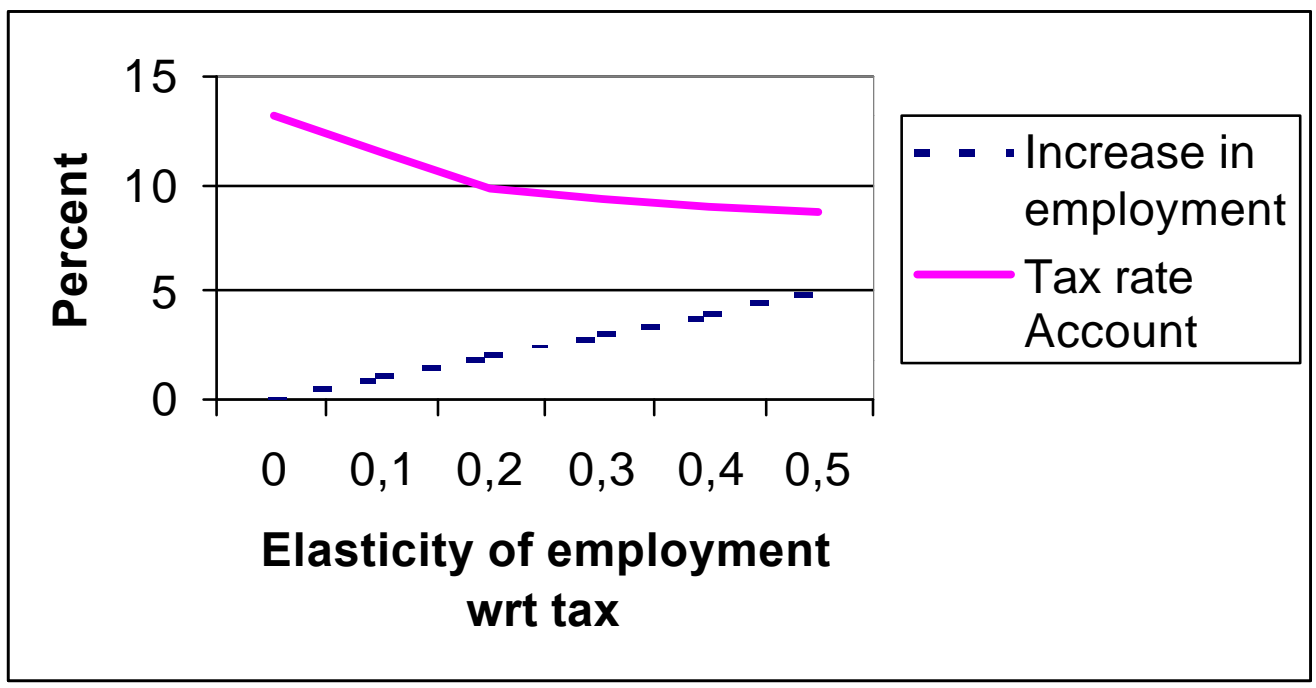

\section{Conclusions}

This paper has examined universal welfare accounts using Swedish data. We find that under fairly general assumptions, if accounts were introduced in Sweden, only a small number of individuals would have negative balances. Under the proposed reform, it is this small group that would be the beneficiary of the government's redistributive policy. Because accounts would allow redistribution based on wealth levels rather than period by period income, they would be cheaper to finance and hence the payroll tax burden on the economy would be lower.

We have developed a projection model to simulate the likely effect of accounts. If the unemployment rate remains the same as at present, then our results suggest that accounts would be associated with a considerably lowered the tax burden. 


\section{Appendix A: Description of Variables}

\begin{tabular}{l|l|l}
\hline Variable & Acronym & Explanation \\
\hline $\begin{array}{l}\text { Taxable factor } \\
\text { income }\end{array}$ & TBI & $\begin{array}{l}\text { The sum of all income from employment, financial capital, } \\
\text { real estate and firm ownership. }\end{array}$ \\
\hline $\begin{array}{l}\text { Taxable labour } \\
\text { market income }\end{array}$ & MINK, AI & Income from employment and from taxed transfers. \\
\hline Total tax & TSK & Total tax paid on taxable factor income and taxed tranfers. \\
\hline Net income & Netink & Taxable factor income and taxed transfers minus total tax. \\
\hline $\begin{array}{l}\text { Disposible } \\
\text { income }\end{array}$ & DISP & Netink plus non-taxed transfers. \\
\hline Wealth & $S F$ & All wealth that is subject to wealth tax. \\
\hline Real estate tax & FSK & Tax on real estate. \\
\hline Incomedecile & Inkdec & $\begin{array}{l}\text { Individuals between } 18 \text { and } 65 \text { are divided into deciles } \\
\text { according to their taxable factor income. }\end{array}$ \\
\hline Incomecareer & $\begin{array}{l}\text { Inkdec } t^{-} \\
\text {Inkdec } t_{-2}\end{array}$ & $\begin{array}{l}\text { Calculated as the individual's income decile in year t minus } \\
\text { her income decile in year t-2. }\end{array}$ \\
\hline
\end{tabular}




\section{References}

Feldstein, M. and D. Altman, (1998), Unemployment insurance savings accounts, NBER Working Paper 6860.

Fölster, Stefan (1998), Social Insurance Based on Personal Savings Accounts: A Possible Reform Strategy for Overburdened Welfare States? European Economy, 81-100.

Fölster, S. (2001) An evaluation of social insurance savings accounts. Public Finance and Management, forthcoming.

Fölster, S. and Trofimov, G. (1999) Social insurance based on personal savings accounts: A theoretical analysis. Working Paper, The Swedish Research Institute of Trade, Stockholm.

Hussénius, J. och Selén, J. (1994), Skatter och socialförsäkringar över livscykeln - en simuleringsmodell. Expertgruppen för Studier i Offentlig Ekonomi, Stockholm, Ds 1994:135.

Orszag, M. J., Orszag, P. R., Snower, D. J., and Stiglitz, J. E. (1999) The impact of individual accounts: Piecemeal vs. comprehensive approaches. Presented at the Annual Bank Conference on Development Economics. The World Bank.

Orszag, Michael, J. and Snower, Dennis (1997) From unemployment benefits to unemployment accounts, Birckbeck College, London, mimeo, June 1997.

Sawyer, M., (1997) Income Distribution in the OECD countries, OECD Economic Outlook. 


\section{IZA Discussion Papers}

$\begin{array}{ll}\text { No. } & \text { Author(s) } \\ 516 & \text { H. Bonin } \\ 517 & \text { E. Tekin } \\ 518 & \begin{array}{l}\text { P. Carneiro } \\ \text { J. J. Heckman }\end{array} \\ 519 & \begin{array}{l}\text { S. Cohen } \\ \text { Z. Eckstein }\end{array} \\ 520 & \text { U. Sunde }\end{array}$

521

U. Sunde

R. Fahr

522

$$
\begin{aligned}
& \text { S.-Å. Dahl } \\
& \varnothing \text {. A. Nilsen } \\
& \text { K. Vaage }
\end{aligned}
$$

J. Falkinger

V. Grossmann

524

J. J. Dolado

F. Felgueroso

J. F. Jimeno

J. J. Heckman

C. Heinrich

J. Smith

E. Leuven

H. Oosterbeek

J. C. van Ours

P. Manzini

M. Mariotti

J. M. Orszag

D. Snower

M. Karanassou

D. Snower

M. Karanassou

H. Sala

D. Snower

D. Snower

533
Title

Area

Date

Eine fiskalische Gesamtbilanz der Zuwanderung

7

06/02

nach Deutschland

Child Care Subsidies, Wages, and Employment

3

of Single Mothers

The Evidence on Credit Constraints in

Post-Secondary Schooling

Labor Mobility of Immigrants: Training,

Experience, Language and Opportunities

Unobserved Bilateral Search on the Labor

Market: A Theory-Based Correction for a

Common Flaw in Empirical Matching Studies

Employment Status, Endogenous Regional

Mobility, and Spatial Dependencies in Labor

Markets

Gender Differences in Early Retirement

Behaviour

5

06/02

06/02

06/02

06/02

Workplaces in the Primary Economy and Wage 3

Pressure in the Secondary Labor Market

Recent Trends in Occupational Segregation by

Gender: A Look Across the Atlantic

2

07/02

The Performance of Performance Standards

6

07/02

A New Approach to Estimate the Wage Returns to Work-Related Training

The Locking-in Effect of Subsidized Jobs

4

Arbitration and Mediation: An Economic

Perspective

Incapacity Benefits and Employment Policy

3

07/02

Unemployment Invariance

3

07/02

Unemployment in the European Union: A

Dynamic Reappraisal

3

07/02

From Unemployment Benefits to Unemployment

3

07/02 Accounts

Assessing Welfare Accounts

3

07/02
R. Gidehag
M. Orszag
D. Snower 